\title{
DEMANDING QUALITY SERVICE: AN EVALUATION OF THE WIRELESS APPLICATION SERVICE PROVIDERS ASSOCIATION (WASPA) CODE OF CONDUCT IN LIGHT OF THE CONSUMER PROTECTION ACT 68 OF 2008
}

\section{$1 \quad$ Setting the scene}

Consumerism has been around for quite some time, giving rise to the need to protect consumers against exploitation by suppliers. In the South African context the impetus to extend protection to consumers of goods and services however only gained proper momentum at the beginning of the 2000s. The Electronic Communications and Transactions Act 25 of 2002 was introduced to provide protection in respect of online transactions. With the introduction of the National Credit Act 34 of 2005 (hereinafter "the NCA") that affords protection to consumers in the credit market (for a general discussion see Scholtz, Otto, Van Zyl, Van Heerden and Campbell Guide to the National Credit Act (2008) Chapter 1) as well as the Consumer Protection Act 68 of 2008 (hereinafter "the CPA") that affords protection to consumers in a wide variety of instances (for a general discussion Naudé and Eiselen Commentary on the Consumer Protection Act (2015)) consumer protection in South Africa has eventually reached an acceptable level.

The CPA, being the most recent in the aforementioned trio of consumer protection legislation, is a comprehensive piece of legislation that extends protection to South African consumers in a wide variety of matters, inter alia, providing them with rights in respect of defective goods, contract terms, franchise agreements, auctions, product liability and so forth. The CPA was signed into law by the President on 24 April 2009 and was put into effect incrementally. The general effective date of the CPA is 31 March 2011 and the regulations issued in terms of the Act were published on 1 April 2011.

It should be noted that before the enactment of the CPA some forms of general consumer protection did exist in South Africa. These forms of consumer protection were, however, not comprehensive in nature and were mainly regulated by the common law or were industry regulated (Woker "Why the Need for Consumer Protection Legislation? A look at some of the reasons behind the promulgation of the National Credit Act and the Consumer Protection Act" 2010 Obiter 217-218). The CPA had however, changed this fragmented landscape of consumer protection, and makes it clear that the comprehensive protection of consumer rights lies at its heart by regulating the following "fundamental" consumer rights, namely the right to: equality in the consumer market; privacy; choice; disclosure and 
information; fair and responsible marketing; fair and honest dealing; fair, just and reasonable terms and conditions; and fair value, good quality and safety and the supplier's accountability to consumers (see Chapter 2 of the CPA). Insofar as the scope of application of the Act is concerned, it is important to note that the CPA applies to both the promotion and to the supply of goods and services to consumers by suppliers in the ordinary course of the suppliers' business and therefore regulates all aspects of the purchasing cycle (s 5(1)). Accordingly, most instances of the supply of goods and services in the Republic of South Africa and the accompanying transactions fall within the ambit of the CPA, unless it is specifically exempted in terms of section 5(2) of the Act (see s 5(1) of the CPA; see further Naudé and Eiselen Commentary on the Consumer Protection Act (2014) 5-1 to 5-44 for a detailed discussion of the scope of application of the CPA).

The fast-developing mobile (cellphone) industry, where products and services improve constantly, necessitates the forging of consumer-brand relationships in order to keep consumers brand loyal and thus to prevent them from switching to competing brands. The South African cellphone industry has been characterised by major growth and is regarded as being one of the fastest-growing industries on the African continent (Sibanda 2008 "South Africa's Mobile Industry Rated Fourth Fastest Growing", http://www.itnewsafrica.com/2008/11/south-africas-mobile-industry-rated-

fourth-fastest-growing/; SouthAfrica.info 2012 "South Africa's Tele-communications" http://www.southafrica.info/business/economy/ infrastructure/telecoms.htm). The number of cellphone users has more than doubled from 12 million in 2005 to 28 million in 2011, constituting $82 \%$ of the adult South African population (South African Advertising Research Foundation 2012). Competition between cellphone brands has also increased as a variety of different cellphone handsets and smart phones have started entering the South African market, making them accessible and affordable to South African consumers, as well as making it easier to switch between brands. South Africa has shown rapid growth in the number of cellphone users, leading the market to reach saturation. This rapid growth has also led to major network congestion and subsequent service problems related to the South African cellphone service provider networks (Sutherland "Counting Mobile Telephones, Sim Cards and Customers" 2008 Link Centre 8-9). Subsequently, customers are showing high levels of customer dissatisfaction, requiring service recovery strategies to be put in place to remedy the situation (Poovalingam and Veerasamy "The Impact of Communication on Customer Relationship Marketing among Cellular Service Providers" 2007 Alternation 87). As it is impossible for service providers to consistently meet and exceed customer needs, service providers need to determine what remedies customers anticipate when their expectations are not met and service failures occur. If service providers are unable to recover from service failures, service providers could experience detrimental results to their profitability and performance, which could furthermore lead to customers switching service providers and engaging in negative word-of-mouth (Chelminski and Coulter "An Examination of Customer Advocacy and Complaining Behaviour in the Context of Service 
Failure" 2011 Journal of Services Marketing 366). According to Bejou and Palmer ("Trust, Ethics and Relationship Satisfaction 1998 International Journal of Bank Marketing 170), it is important for a service business to determine their customer types and how long customers have been dealing with them (consumption stage), as this will influence how customers will react when faced with poor service and service failures and how easily they will switch to a substitutable product and new service provider.

This note will examine the right to fair value, good quality, and safety in respect of services provided by mobile "service providers" in South Africa with particular reference to the CPA as well as the WASPA Code of Conduct for the mobile service provider industry.

\section{The right to fair value, good quality and safety in terms of the CPA}

\section{Important definitions}

A person who wishes to assert the right to demand quality services as provided for by section 54 of the CPA, must be a "consumer" as contemplated in the CPA and, as indicated above, "goods" or "services" as defined in the Act (see s 1) must have been promoted or supplied to such a consumer by a "supplier" in the ordinary course of the supplier's business. Accordingly, it is necessary to provide an overview of these important concepts before embarking on a discussion of section 54 of the CPA in respect of a consumer's right to demand quality services.

Section 1 of the CPA contains a wide definition of the concept "consumer" "in respect of any particular goods or services" a "consumer" inter alia denotes:

(i) a person to whom those particular goods or services are marketed in the ordinary course of the supplier's business;

(ii) a person who has entered into a transaction with a supplier in the ordinary course of the supplier's business, unless the transaction is exempt from the application of this Act by section 5(2) or in terms of section $5(3)$;

(iii) if the context so requires or permits, a user of those particular goods or a recipient or beneficiary of those particular services, irrespective of whether that user, recipient or beneficiary was a party to a transaction concerning the supply of those particular goods or services; and

(iv) a franchisee in terms of a franchise agreement, to the extent applicable in terms of section $5(6)(b)-(e)$.

"Goods" for purposes of the CPA are also broadly defined and includes:

"(a) anything marketed for human consumption; (b) any tangible object not otherwise contemplated in aforesaid paragraph including any medium on which anything is or may be written or encoded; (c) any literature, music, photograph, motion picture, game, information, data, software, code or other intangible product written or encoded on any medium, or a licence to use any 
such intangible product; (d) a legal interest in land or any other immovable property, other than an interest that falls within the definition of "service" in this section; and (e) gas, water and electricity" (s 1 of the CPA).

In order to extend the widest possible protection in the context of services, the concept "services" includes, but is not limited to:

"(a) any work or undertaking performed by one person for the direct or indirect benefit of another; (b) the provision of any education, information, advice or consultation, except advice that is subject to regulation in terms of the Financial Advisory and Intermediary Services Act 37 of 2002; (c) any banking services, or related or similar financial services, or the undertaking, underwriting or assumption of any risk by one person on behalf of another, except to the extent that any such service (i) constitutes advice or intermediary services that is subject to regulation in terms of the Financial Advisory and Intermediary Services Act, 2002 (Act 37 of 2002); (ii) or is regulated in terms of the Long-term Insurance Act, 1998 (Act 52 of 1998) or the Short-term Insurance Act, 1998 (Act 53 of 1998); (d) the transportation of an individual or any goods; (e) the provision of - (i) any accommodation or sustenance; (ii) any entertainment or similar intangible product or access to any such entertainment or intangible product; (iii) access to any electronic communication infrastructure; (iv) access, or of a right of access, to an event or to any premises, activity or facility; or (v) access to or use of any premises or other property in terms of a rental; ( $f$ ) a right of occupancy of, or power or privilege over or in connection with, any land or other immovable property, other than in terms of a rental; and $(\mathrm{g})$ rights of a franchisee in terms of a franchise agreement to the extent applicable in terms of section 5(6)(b) to (e), irrespective of whether the person who promotes, offers or supplies the services participates directly in the services or supervises it or is directly or indirectly involved therein" (s 1 of the CPA). This also includes advertising (see s 5(1)(b)(i)-(ii)).

Suppliers play a central role in the CPA as the protection that the Act affords to consumers is mainly directed against suppliers. A "supplier" is any person who markets goods or services. To "market" means to "supply" or "promote" goods or services. In terms of section 1, "promote" means to advertise, display, or offer to supply services or goods in the ordinary course of business for consideration. It also means making any representation in the ordinary course of business that could be inferred as expressing willingness to supply services or goods for consideration or engagement in any other conduct in the ordinary course of business that could reasonably be construed to be an inducement or attempted inducement to a person to engage in a transaction. "Supply" in relation to goods includes to sell, rent, exchange and hire in the ordinary course of business for consideration, and in relation to services, it means to sell services, to perform or to cause services to be performed or provided, and to grant access to premises, events, activities or facilities in the ordinary course of business for consideration. These definitions of "supply" and "supplier" are wide, and the Act will, therefore, affect a very wide range of suppliers of goods and services notably also the mobile service industry. In other words, the mobile service industry must align their industry codes with the provisions of the CPA and other consumer legislation in order to not fall foul of the protection afforded to consumers by the CPA.

In addition to the all-important definitions of "goods" and services", "transaction" means - 
(a) in respect of a person acting in the ordinary course of business -

(i) an agreement between or among that person and one or more other persons for the supply or potential supply of any goods or services in exchange for consideration; or

(ii) the supply by that person of any goods to or at the direction of a consumer for consideration; or

(iii) the performance by, or at the direction of, that person of any services for or at the direction of a consumer for consideration; or

(b) an interaction contemplated in section 5(6), irrespective of whether it falls within paragraph (a)" (s 1 of the CPA).

\section{Section 54 of the CPA: Consumer's rights to demand quality services}

Section 54(1) of the CPA provides consumers with the right to fair value, good quality, and safety in the context of services. This section provides for four standards to which services must conform and which consumers are entitled to (Naudé and Eiselen Commentary on the Consumer Protection Act 54-10): (i) the timely performance and completion of those services, and timely notice of any unavoidable delay in the performance of the services (s $54(1)(a))$; (ii) the performance of the services in a manner and quality that persons are generally entitled to expect (s 54(1)(b)); (iii) the use, delivery or installation of goods that are free of defects and of a quality that persons are generally entitled to expect, if any such goods are required for performance of the services (s 54(1)(c)); and (iv) the return of any property or control over any property of the consumer in at least as good a condition as it was when the consumer made it available to the supplier for the purpose of performing such services having regard to the circumstances of the supply, and any specific criteria or conditions agreed between the supplier and the consumer before or during the performance of the services (s 54(1)(d)).

When regard is had to section 54(1) the definitions of "supply," "services" and "service provider" as set out above are important. It is also clear that the circumstances of supply must be taken into account, especially to determine whether the standards set out in section 54 were complied with or not (Naudé and Eiselen Commentary on the Consumer Protection Act 54-10). Note should be taken that section 51(1) prohibits the use of terms in an agreement, which directly or indirectly waive or deprive a consumer of a right in terms of the CPA. A consumer's rights under section 54(1) may thus not be excluded by a contrary agreement - however Naudé and Eiselen point out that "an agreement between the parties on the quality of the services would influence what the consumer may reasonably expect in this regard which will indirectly limit a service provider's liability by defining the limits of the service clearly" (Naudé and Eiselen Commentary on the Consumer Protection Act 54-10). In order to determine what constitutes timely performance in terms of section 54(1)(a) it is important to have regard to not only the specific criteria or conditions agreed to between the supplier and the consumer before or during the performance of services but also to instances 
when the parties have not agreed to the circumstances of supply. Jacobs, Stoop and Van Niekerk ("Fundamental Consumer Rights under the Consumer Protection Act 68 of 2008: A Critical Overview and Analysis" 2010 12 PELJ 301365$)$ point out that with reference to punctual performance and completion of the services and timely notice of any unavoidable delay in performance that "it is uncertain what would constitute 'timely notice'”. What constitutes "timely notice" would be dependent on the specific case. In this regard section 54(1) should also be read with section 19 specifically with regard to the provision in section 19 that

"unless otherwise expressly provided or anticipated in an agreement, it is an implied condition of every transaction for the supply of goods and services that (a) the supplier is responsible to deliver the goods or perform services (i) on the agreed date and at the agreed time, if any or otherwise within a reasonable time after concluding the transaction or agreement ..."

Naudé and Eiselen remark:

\begin{abstract}
"Note that service providers may elect to insert terms and conditions as long as this does not infringe upon a consumer's right to contracts which are fair, reasonable and just. So for instance, a service provider could include a clause in which it provides that the delivery times provided to the consumer are only estimates. However, if the service provider includes a term, which gives an unreasonably long time to perform, such a term will be presumed to be unfair in terms of reg 44. This means that if a consumer alleges that the term is unfair, the supplier will have to justify why it is considered fair under the circumstances. Section 54 also creates the opportunity to regulate the time of performance contractually" (Naudé and Eiselen Commentary on the Consumer Protection Act 54-11).
\end{abstract}

A supplier, however, can escape liability where a timely notice of an unavoidable delay was served to a consumer indicating that the delay is due to circumstances beyond the supplier's control which makes it impossible to perform the services on time (see also s 47 of the CPA and Naudé and Eiselen Commentary on the Consumer Protection Act 54-11). Section 54(2)(a) of the Act further provides that a consumer is entitled to ask a supplier, where a delay in delivery of a service was not unavoidable, to remedy any defect in the quality of service that was subsequently rendered.

In addition to the above, a consumer is also entitled to expect that services be performed in a manner and quality that "persons are generally entitled to expect." Section 54(1) thus contains a broad "consumer expectations test" that covers the manner and quality in which services are to be rendered. It is submitted that the application of this broad test to the "manner" in which services are rendered actually covers the other aspects mentioned in section 54(1)(a) and (c) and (d). The consumer expectations test is a test that has been regarded as notoriously complex in other jurisdictions such as the United Kingdom and Australia and in the South African context one can expect that its application will also be challenging especially given the diverse nature of South African consumers (see Loubser and Reid "Fundamental Consumer Rights" in Naudé and Eiselen Commentary on the Consumer Protection Act (2014) 53-4). Jacobs, Stoop and Van Niekerk point out that the degree of performance that should be met with respect to the manner and quality that persons (not merely 
consumers) are generally entitled to expect is a factual question (Jacobs, Stoop and Van Niekerk 201012 PELJ 365). What a person generally will be entitled to expect with regard to certain services will also in part be influenced by expectations created by the contract between the parties (Naudé and Eiselen Commentary on the Consumer Protection Act 54-14). For example the requirement in section 54(1)(a) regarding timely performance does not imply that a service should be available $100 \%$ of the time, as it can be accepted of consumers to generally expect "occasional and temporary outages" (Naudé and Eiselen Commentary on the Consumer Protection Act 54-15). It, therefore, appears that the legislator, in essence, manages the consumer's expectations by providing in sections 54(1)(a), (c) and (d) what consumers can expect.

As indicated section 54(1)(c) further provides that a consumer has the right to the "use, delivery or installation of goods that are free of defects and of a quality that persons are generally entitled to expect, if any such goods are required for the performance of the service" (see also Jacobs, Stoop and Van Niekerk 201012 PELJ 365 in this regard) (Save to make the point that consumers are entitled to use, delivery or installation of safe, good quality goods; a detailed analysis of this subsection goes beyond the current discussion as it deals also with defects and liability in terms of s 61 for defective goods).

Lastly, section $54(1)(d)$ provides that a supplier must return the property or control over the property of the consumer to the consumer in at least as good condition as it was when the consumer made it available. Naudé and Eiselen provide the following example of this type of service: where a consumer leaves his/her car at a service station or panel beater for repairs or any service where the consumer takes a product to the service provider for repairs or maintenance. In this regard, Jacobs, Stoop and Van Niekerk point out "that it may be a difficult burden for the consumer to prove that the supplier returned the property in a worse condition than when it was made available to him/her" (Jacobs, Stoop and Van Niekerk 201012 PELJ 365). It must, however, be noted that a supplier may no longer contract out of liability for loss or damage to the consumer's property in the event that such a loss of or damage to property was as a result of the supplier's negligence. A clause contracting out of such liability will contravene section 51(1)(b)(ii) of the CPA.

If a supplier fails to perform a service in accordance with the aforementioned standards, the CPA provides that the consumer may require the supplier to either remedy any defect in the quality of the services performed or goods supplied; or refund to the consumer a reasonable portion of the price paid for the services performed and goods supplied, having regard to the extent of the failure (see s 54(2) in this regard). 


\section{The impact of section 54 of the CPA on the provisions in Industry Codes relating to services}

Having dealt with the manner and quality of service as provided for in section 54(1) of the CPA it is submitted that these provisions also impact on the content of industry codes for suppliers in a particular industry in so far as such codes deal with service delivery. An industry code is defined in section $82(1)$ of the CPA as a code "(i) regulating the interaction between or among persons conducting business within an industry; or (ii) regulating the interaction, or providing for alternative dispute resolution, between a person contemplated in subparagraph (i) and consumers." It is to be noted that section 82(4) of the CPA specifically provides that an industry code must be consistent with the purposes and policies of the Act. Accordingly, service providers will not only be required in their codes to adhere to the provisions of the CPA regarding quality services but will also have to observe the provisions of the CPA relating to aspects such as the promotion of fair business practices, unconscionable, unfair, unreasonable, unjust and improper trade practices and deceptive, misleading, unfair or fraudulent conduct (see particularly part E and F of Chapter 2 the CPA dealing with marketing and advertising practices).

\section{The Wireless Application Service Providers Association (WASPA)}

Mobile Telephone Networks (Pty) Ltd $v$ National Consumer Commission (NCT/2738/2011/101 (1) (P) [2012] ZANCT 3) dealt with whether a compliance notice as provided for in section 100 of the CPA could be issued by the National Consumer Commission to the applicant (MTN). The consumer agreements that formed the subject matter of the compliance notice were, in fact, entered into between consumers and a separate juristic person (MTNSP) licenced by the applicant to provide services and who was a sister company to the applicant in the "MTN Group of Companies." The applicant was not a direct party to the agreements, and as such contended that they were the incorrect party to issue the compliance notice to (par 9).

The NCC contended that this was merely a technical point, that the applicant was licenced by the Independent Communications Authority of South Africa (ICASA) not its sister's company and that the two juristic persons were, in fact, one and the same or a conduit of the other (par 102 ).

The National Consumer Tribunal in hearing the matter indicated that the CPA is new legislation and as such, there is a limited jurisprudence on how it is to be interpreted. The Tribunal remarked that it looked to foreign jurisdictions as authorised by section 92(2) to determine whether a distinct legal entity (MTN), could be cited and held responsible for the interactions between another distinct legal entity (MTNSP) and consumers, and whether there were policy considerations in favour of piercing the corporate veil. The general requirements that were found to warrant such a departure were; "firstly that there is such a unity of interest and ownership between the corporation and the individual or the organization controlling it that their 
separate identities no longer exist and secondly failure to disregard the corporate entity would sanction a fraud or promote an injustice" (par 25).

The Tribunal found that there was in fact, such a unity of interest and ownership between the corporation and the individual or organisation controlling it that their separate personalities no longer existed; failure to disregard the corporate identity would sanction a fraud or promote an injustice; that justice and equity would be best accomplished and fraud and unfairness defeated by disregarding the distinct entity of the corporate form. As such the applicant was found to be the correct party to whom the compliance notice should have been issued to. This case accordingly makes it clear that wireless application service providers can be held accountable in terms of the CPA for the actions of their licencees (par 38).

In this context, note must be taken that the Electronic Communications Act (36 of 2005 in s 69), Code of Conduct, end-user and subscriber service charter, provides that:

(1) The Authority must, as soon as reasonably possible after the coming into force of this Act, prescribe regulations setting out a code of conduct for licensees subject to this Act and persons exempted from holding a licence in terms of section 6 to the extent such persons provide a service to the public.

(2) The Authority may develop different codes of conduct applicable to different types of services. All electronic communications network services licence and electronic communications service licensees must comply with the Code of Conduct for such services as prescribed.

(3) The Authority must, as soon as reasonably possible after the coming into force of this Act, prescribe regulations setting out the minimum standards for end-user and subscriber service charters.

(4) The Authority may develop different minimum standards for end-user and subscriber service charters for different types of services.

(5) The matters which an end-user and subscriber service charter may address include, but are not limited to -

a) the provision of information to end-users and subscribers regarding services, rates, and performance procedures;

b) provisioning and fault repair services;

c) the protection of private end-user and subscriber information;

d) end-user and subscriber charging, billing, collection and credit practices;

e) complaint procedures and the remedies that are available to address the matters at issue; and

f) any other matter of concern to end-users and subscribers.

(6) Where an end-user or subscriber is not satisfied after utilising the complaint procedures set out in the regulations, his or her complaint may be submitted to the Authority in accordance with the provisions of section $17 \mathrm{C}$ of the ICASA Act. 
In addition, section $17 \mathrm{C}$ of the Independent Communications Authority of South Africa (ICASA) Act (13 of 2000) provides,

"(a) A person who has reason to believe that a licensee or another person is guilty of any non-compliance with -

(i) the terms and conditions of a licence;

(ii) this Act; or

(iii) the underlying statutes,

may lodge a complaint with the Authority within 60 days of becoming aware of the alleged non-compliance.

(b) The Authority may -

(i) where the complaint concerns a licensee, direct the complaint within 30 days of receipt of the complaint, to the Complaints and Compliance Committee for consideration;

(ii) where the complaint concerns a person who is not a licensee, lay a charge against that person with the appropriate authority or institution or refer the matter to the appropriate authority or institution in terms of a concurrent jurisdiction agreement concluded between the Authority and that authority or institution within 30 days of receipt of the complaint; or

(iii) investigate the complaint as contemplated in section 4(3)(n)."

At this point, it is apposite to make a few observations regarding selfregulation by industry bodies: In order for self-regulation to be truly effective there must be an industry body that has the capacity to monitor the industry and to deal with transgressors effectively by laying down sanctions for noncompliance and for the transgression of their code. An industry body can ensure that certain standards of behaviour are maintained or at least encouraged in a particular industry. Such standards of behaviour can also provide the consumer with a useful starting point when they lodge a complaint as well as provide them guidance to a regulatory body to ensure the protection of consumer interests. Self-regulation "is often more effective than government regulation because experts in the industry are able to identify genuine abuses far more readily than government officials and there is less control over legitimate activities" (see in this regard Woker The Franchise Relationship under South African Law (2012) 580; see also Woker "Consumer Protection and Alternative Dispute Resolution" 2016 SA Merc LJ 31-32). It is also easier for a specific industry or sector to update their codes or standards of conduct and address concerns and problems associated with that particular industry. The amendment process of such a code is also subjected to the tedious and cumbersome process to which legislation is subjected to when amendments must be effected.

The WASPA is a non-profit, self-regulating body that represents the interests of mobile application service providers operating in South Africa (www.waspa.org.za/coc).WASPA provides a neutral forum for members to address issues of common interest and interact with industry stakeholders, network operators and government bodies (WASPA COC s1.1). WASPA aims to ensure that consumers receive world-class services and that members operate according to ethical and reasonable business practices (WASPA COC s1.2). The WASPA Code of Conduct was developed as part 
of an industry self-regulatory framework. The updated version of this Code of Conduct became effective on 26 August 2014 (WASPA COC).

It is stated that the Objectives of the Code are to ensure that members of the public can use mobile services with confidence, assured that they will be provided with accurate information about all services and the pricing associated with those services. The Code aims to equip customers and consumers with a mechanism for addressing any concerns or complaints relating to services provided by WASPA members, and a framework for impartial, fair and consistent evaluation and response to any complaints made (WASPA COC s1.3).

Some noteworthy changes to the Code of Conduct that came into effect in 2014 being:

(i) Competition Terms and Conditions have been succinctly provided for in section 5 . These were previously scattered in various sections of the Code. The section also includes a checklist and template to ensure that sufficient detail about the terms and conditions are delivered. The section is however, not as detailed as the relevant provisions in the CPA which leaves much room for ambiguity, for example there is no mention made of the fact that terms should not be unfair, unreasonable or unjust (s 48 (1)(a)(ii) of CPA) nor that consumers' attention should be drawn to terms or conditions that purport to waive or limit the liability of the supplier (s 48(1)(c)(ii) of CPA) requirements explicitly provided for in the CPA.

(ii) Advertising requirements have been set out in sections 8 to 13 of the Code. The requirements have been defined per type of service, i.e. TV, Cinema, Radio, Print, Web and USSD and clear guidelines for each have been provided regarding pricing information that should be accurate and not misleading as well as the display of minimum terms and conditions that should be provided. This is more aligned with the CPA and less open to interpretation. The CPA requires that goods not be marketed in a manner that is misleading, fraudulent or deceptive in respect of among others; the price at which goods will be supplied ( $\mathrm{s}$ 29(b)(iii) of CPA) and the manner in or conditions on which the goods or services will be supplied (s 29(b)(ii) of CPA).

(iii) Cellphone confirmation is dealt with by section 12 of the Code. This entails the capturing of cellphone numbers by means of a web form and the onus is now on the service provider to prove that the number belongs to the person who completed the form. This is done by using a one-time pin or a link sent via SMS to the relevant cellphone number. The purpose thereof is to prevent the unauthorised "selling" of cellphone numbers to databases. Subscription services can be found in section 15 of the Code. This section has been rewritten to bring more clarity to an area that has traditionally been misused, to the detriment of consumers: the "DoubleOpt-In" process is now a requirement to ensure that consumers are not subscribed to services that they did not request or were unaware of. This aligns the Code to the prohibition of unsolicited goods or services ( $\mathrm{s}$ $21(1)(e)$ of CPA). The CPA provides that if goods are delivered or services performed, without the consumer having expressly or implicitly 
requested such, they may be considered unsolicited goods. It would appear that the addition of the "Double-Opt-In" process provides added protection for consumers.

(iv) Direct Marketing is covered by section 16 of the Code and means to approach a person, either in person or by mail or electronic communication, for the direct or indirect purpose of -

(a) promoting or offering to supply, in the ordinary course of business, any goods or services to the person; or

(b) requesting the person to make a donation of any kind for any reason.

The sections referring to direct marketing were previously found interspersed in the Code of Conduct; this new section amalgamates these sections. This section in the COC is aligned to the CPA that contains a similar definition of direct marketing. Moreover, like the CPA it inter alia provides for the times during which direct marketing may take place (s 12(2) of CPA).

Although Opt-out keywords are not new, they have once again been included and expanded to include any of the following: "END", "CANCEL", "UNSUBSCRIBE", "QUIT" or "STOP". There is an apparent conflict between the Opt-out provided for by the CPA and that provided for the Code of Conduct and the requirements of the Protection of Personal Information (PoPI) Act 4 of 2013. PoPI provides (in brief) that: suppliers cannot engage in direct marketing without a person's consent,

(i) unless that person is an existing customer,

(ii) who provided their contact details for the purpose of direct marketing during the course of a transaction for the same or similar goods or services,

(iii) and has been given ample opportunity to opt-out every time direct marketing is done and that the supplier can contact the customer once to get this consent.

This is essentially an Opt-in system, although which will apply remains to be seen (De Stadler "Direct Marketing: Opt-out Registry still in the works?" 2013 Juta Consumer LR 1).

Section 69(2) of the PoPI Act allows a responsible party to approach a data subject once, to request consent for the sending of direct marketing material, provided that consent has not previously been withheld. The allowance provided in this section is strongly criticized by authors due to its scope for abuse and because, in essence, it reverts back to an opt-out model. It is contended that, by allowing a responsible party to process personal information "once" to make the approach to obtain consent, the prohibition in section $69(1)$ is reduced to a second level protection mechanism. Meaning that it only becomes relevant after the approach has been made. It is also in conflict with the position established in regulation 4 of the CPA where a direct marketer must, without exception, assume that a comprehensive pre-emptive block has been registered by a consumer. (Hamann and Papadopoulos "Direct Marketing and Spam via Electronic 
Communications: An Analysis of the Regulatory Framework in South Africa" 2014 De Jure 42-62).

According to WASPA, its aim is to represent the interests of both its members and the consumers who use members' services. WASPA can sanction members who break the rules with penalties that range from hefty fines to suspension from the organisation. It is WASPA's goal to protect consumers to the best of its ability, by making regular revisions of the Code of Conduct. By staying on top of changes in legislation and constantly adjusting the Code in order to remain relevant to the industry, WASPA seeks to provide the levels of protection that give both customers and members a real sense of security (WASPA COC).

The measures that are provided by the new Code of Conduct seem to provide sufficient protection for consumers whilst still balancing the interests of service providers. Although it does not expressly state the remedies that are available to consumers as it is stated in the CPA, in section 24 of the Code, it does provide an informal and formal complaints procedure that may be followed. The choice of which is based on the feasibility of a prompt remedy and where no material breach of the Code seems to have occurred. This would seem to be a broad remedy section that consumers can rely on. The introduction of a "Media Monitor," a type of informal ombudsman, is also a good avenue of redress that consumers may rely on when a remedy is sought. Overall, the Code provides clearer guidelines as to acceptable and unacceptable behaviours by service providers, a measure seemingly to ensure that ignorance is no longer an excuse.

\section{$6 \quad$ Concluding remarks}

Many examples of "consumer activism in South Africa" exist, sites like hellopeter.com where consumers can lodge complaints against service providers if they are unsatisfied with their service delivery or response times, or how a complaint has been dealt with (see also in this regard http://www.werksmans.com/staging/legal-briefs-view/the-anti-ad-billboard-anew-dawn-for-consumer-activism/) are often used by consumers. Social media has not only changed the way people communicate with each other but has also changed the manner in which consumers deal with bad service. Companies now have dedicated pages, which specifically deal with complaints and problems associated with their service delivery and products.

When consumers become frustrated with service delivery and the resolution of a dispute, they may resort to creative ways to get the attention of the service provider. One such case is that of the consumer versus Cell C: a dispute arose between a customer ("the consumer") of a mobile network service provider ("Cell C" Sandton City). Reports (both on social and conventional media) reported that the consumer entered into a contract with the service provider on behalf of his son. The consumer then discovered that the cellphone number in question had also been allocated to an unrelated third-party consumer who had run up a bill of over R5,000. The consumer consequently lodged a complaint with the Cell $\mathrm{C}$ and stopped all payments relating to that contract. The consumer in 2014 discovered that Cell $\mathrm{C}$ had 
blacklisted him when he attempted to purchase a car. The consumer then warned Cell $\mathrm{C}$ that unless his complaint was resolved and the blacklisting removed, he would erect a billboard to the effect of his experience of bad customer service. Cell C did nothing in response to this threat (see also in this regard http://www.werks-mans.com/staging/legal-briefs-view/the-anti-adbillboard-a-new-dawn-for-consumer-activism/).

The consumer then took out a prominent billboard that Cell C Sandton City was "The most useless service provider in SA," only then did Cell C respond saying that the billboard should be removed. When their demands were not met, Cell $\mathrm{C}$ instituted an urgent court application to have the billboard taken down. They claimed that the billboard was defamatory, made unauthorised use of its trademark, and appeared to have been put up in contravention of the law. The High Court ruled that the application was not urgent and dismissed it on the basis that the service provider should have brought the application when the consumer first threatened to put the billboard up and that "It appears that the damage - if any - has already been done". The anti-ad billboard could, therefore, stay (see also in this regard http://www.werksmans.com/staging/legal-briefs-view/the-anti-ad-billboard-anew-dawn-for-consumer-activism/).

The failure by Cell $C$ to provide a proper service to its customer by, inter alia, dealing with the customer's complaint directly caused the consumer's "negative" action. In addition, Cell C the service provider, could have made use of section 72(1)(a) of the National Credit Act (34 of 2005) and informed the consumer that it intended to report him to the credit bureau, providing the consumer with the opportunity to challenge the accuracy of the information. Had Cell C committed itself to the standard of service provisions set out in the Code, as "endorsed" by the CPA, this matter might have had a more positive outcome for both parties.

The changes introduced by the WASPA Code of Conduct are a welcome step in the right direction, providing a clearer framework of acceptable and unacceptable behaviour by service providers. It mirrors in certain instances the CPA and thus has a consumer-centric approach. Whether it will make any meaningful difference to consumers, such as the one mentioned above, remains to be seen. The buy-in of credit providers and suppliers will be essential in establishing a culture of better service delivery by cellphone providers.

Leander Kruger

Nelson Mandela University

Monray Marsellus Botha University of Pretoria 